\title{
IbM PELATIHAN PEMBERDAYAAN KELOMPOK TANI DOSROHA DAN KELOMPOK TANI WANITA BERKARYA PADA DESA HUTAPAUNG
}

\author{
Romasi Lumban Gaol \\ Esli Silalahi
}

\begin{abstract}
Abstrak
Kelompok tani Dosroha dan kelompok tani Wanita Berkarya Desa Hutapaung merupakan bagian dari anggota Pemberdayaan dan Kesejahteraan Keluarga (PKK). Anggota Kelompok tani Dosroha dan kelompok tani Wanita Berkarya Desa Hutapaung yang menjadi mitra Pengabdian pada Masyarakat ini belum bisa mengolah ubi jalar untuk berbagai aneka produk pangan olahan guna meningkatkan nilai tambah ubi jalar karena minimnya pengetahuan teknologi pengolahan ubi jalar yang dimiliki petani, dan peralatan yang tidak dimiliki. Dari aspek teknologi pangan dan pengolahan hasil pertanian, pendapatan petani masih bisa ditingkatkan. Ubi jalar bisa dimanfaatkan menjadi keripik ubi yang bernilai tambah. Metode pelakanaan IbM di lakukan dengan 1) Penyediaan peralatan Teknologi Tepat Guna yang dibutuhkan, seperti alat pengiris ubi dan spinner peniris minyak, 2) Pelatihan penggunaan alat teknologi tepat guna, 3) Pelatihan penentuan harga pokok produksi dan harga jual dilakukan dengan cara memperhitungkan harga bahan baku, upah pekerja, dan biya-biaya lain yang berkaitan dengan produk tersebut, pengemasan, dan pemasaran, 4) Pelatihan pembuatan pembukuan sederhana, 5) Pelatihan berupa pemasaran dengan menggunakan media sosial. Hasil dari kegiatan ini adalah 1) Diserahkan beberapa peralatan Teknologi Tepat Guna yaitu 1 unit mesin pengiris ubi, 1 unit mesin spinner peniris minyak, 2) Mitra memperoleh pemahaman tentang penggunaan Teknologi Tepat Guna yang bertujuan untuk meningkatkan nilai tambah dari ubi jalar, 3) Mitra dapat menentukan harga pokok produksi per kg produk keripik ubi dan harga jual per kg produk keripik ubi, 4) Mitra mampu menyusun pembukuan sederhana untuk usaha pengolahan keripik ubi jalar. Luaran dari kegitan ini berupa, Laporan kegiatan, Artikel, Blog promosi produk kelompok tani Dosroha dan kelompok tani Wanita Berkarya.
\end{abstract}

Kata Kunci : ubi jalar ungu, keripik ubi ungu, harga pokok produksi.

\section{PENDAHULUAN Analisis Situasi}

Ubi ungu bermanfaat sebagai antioksidan karena dapat menyerap polusi udara, racun, oksidasi dalam tubuh, dan menghambat penggumpalan sel-sel darah. Ubi ungu juga mengandung serat pangan alami yang tinggi, prebiotik, kadar Glycemic Index rendah, dan oligosakarida. Selain itu, ubi ungu juga mengandung lisin, $\mathrm{Cu}, \mathrm{Mg}, \mathrm{K}, \mathrm{Zn}$ rata-rata $20 \%$. Jenis umbian ini juga merupakan sumber karbohidrat dan sumber kalori yang cukup tinggi. Yang mengandung vitamin dan mineral, misalnya vitamin A, vitamin C, thiamin (vitamin B1), dan riboflavin. Sedangkan mineral dalam ubi jalar diantaranya adalah zat besi $(\mathrm{Fe})$, fosfor $(\mathrm{P})$, 
dan kalsium (Ca). Kandungan lainnya adalah protein, lemak, serat kasar dan abu. Total kandungan antosianin bervariasi pada setiap tanaman dan berkisar antara 20 $\mathrm{mg} / 100 \mathrm{~g}$ sampai $600 \mathrm{mg} / 100 \mathrm{~g}$ berat basah. Total kandungan antosianin ubi jalar ungu adalah $519 \mathrm{mg} / 100 \mathrm{~g}$ berat basah. Antosianin ubi ungu juga memiliki fungsi fisiologis misal antioksidan, antikanker, antibakteri, perlindungan terhadap kerusakan hati, penyakit jantung dan stroke. Ubi ungu bisa menjadi anti kanker karena didalamnya ada zat aktif yang dinamakan selenium dan iodin dan dua puluh kali lebih tinggi dari jenis ubi yang lainnya. Ubi jalar ungu memiliki aktivitas antioksidan dan antibakteri 2,5 dan 3,2 kali lebih tinggi daripada beberapa varietas "blueberry", selain itu juga baik untuk mendorong kelancaran peredaran darah.

Desa Hutapaung termasuk dari tiga belas desa yang ada di wilayah Kecamatan Pollung Kabupaten Humbahas, dengan jarak dari kota Medan kirakira $\pm 240 \mathrm{~km}$ (duaratus empatpuluh kilometer) dan jarak tempuh kira-kira 6 jam. Desa ini terdiri dari 337 kepala keluarga, dengan jumlah penduduk 1.557 jiwa, terdiri dari 766 jiwa laki-laki $(49,20 \%)$ dan 791 jiwa perempuan $(50,80 \%)$. Bila ditinjau berdasarkan mata pencaharian maka $79 \%$ keluarga bermata pencaharian petani, $7 \%$ pedagang dan $10 \%$ PNS dan pegawai swasta, dan $4 \%$ adalah lainnya.

Kelompok tani Dosroha dan kelompok tani Wanita Berkarya Desa Hutapaung merupakan bagian dari anggota Pemberdayaan dan Kesejahteraan Keluarga (PKK). Desa Hutapaung merupakan mitra kerja Pemerintah dalam pembangunan masyarakat. Kelompok Tani di desa Hutapaung sebagai mitra pengabdian sudah terbentuk mulai tahun 2008 tetapi hingga saat ini kelompok tani belum penah diberdayakan untuk membantu memajukan kesejahteran desa. Usaha-usaha yang telah mereka jalankan selama ini sebagai kelompok tani hanya sebatas menanam padi dan menanam ubi jalar yang langsung dijual kepasaran, dimana harga jual ubi jalar tidak sebanding dengan biaya, tenaga dan waktu yang digunakan selama proses mulai penanaman sampai panen ubi jalar.

Ladang ubi jalar di desa Hutapaung cukup luas, gambar 1.1 menunjukkan bahwa begitu luasnya ladang ubi jalar yang ada di daerah ini dan menghasilkan buah yang cukup sebagai bahan baku untuk pembuatan keripik ubi jalar.

Gambar ladang ubi jalar yang tumbuh subur di desa Hutapaung

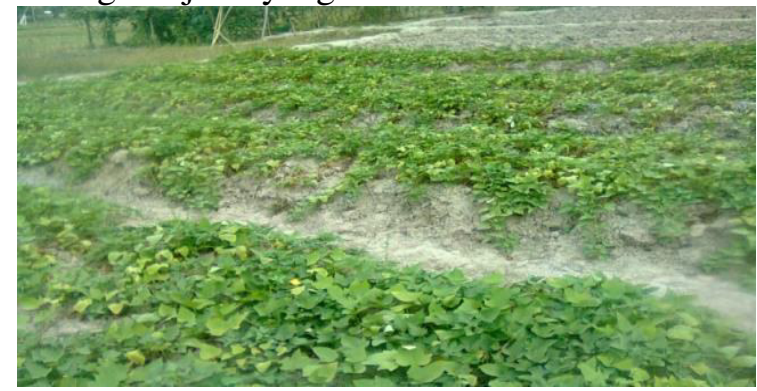

Gambar 1. Ladang ubi jalar 
Masalah utama dalam usaha tani ubi jalar di desa Hutapaung adalah ketidakstabilan harga dan ketidakpastian pasar. Harga komoditas ubi jalar sering tidak stabil dengan fluktuasi harga yang cukup besar. Harga rata-rata ubi jalar

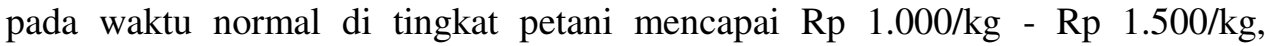
sedangkan harga rata-rata ubi jalar yang dijual di pasar adalah Rp 2.500/kg. Pada waktu panen raya, harga rata-rata ubi jalar mengalami penurunan menjadi $\mathrm{Rp}$ $500 / \mathrm{kg}$, sedangkan harga rata-rata ubi jalar yang dijual di pasar adalah $\mathrm{Rp}$ $1.500 / \mathrm{kg}$. Sehingga harus dibiarkan oleh petani sampai busuk, atau tudak di panen karena biaya panen menjadi lebih tinggi dari harga jual.

Anggota Kelompok tani Dosroha dan kelompok tani Wanita Berkarya Desa Hutapaung yang menjadi mitra Pengabdian pada Masyarakat ini belum bisa mengolah ubi jalar untuk berbagai aneka produk pangan olahan guna meningkatkan nilai tambah ubi jalar karena minimnya pengetahuan teknologi pengolahan ubi jalar yang dimiliki petani, dan peralatan yang tidak dimiliki. Kelompok tani ini pernah mencoba mengolah ubi jalar menjadi keripik ubi dengan peralatan manual tapi hasilnya melempem dan tidak tahan lama, sehingga tidak laku terjual. Dari aspek teknologi pangan dan pengolahan hasil pertanian, pendapatan petani masih bisa ditingkatkan. Ubi jalar bisa dimanfaatkan menjadi keripik ubi yang bernilai tambah.

Selain itu kelompok tani Dosroha dan kelompok tani Wanita Berkarya Desa Hutapaung sulit menentukan harga jual produk olahannya karena kurangnya pemahaman tentang proses perhitungan harga pokok dan harga jual.

\section{Permasalahan Mitra}

Berikut ini adalah hasil identifikasi kami terhadap permasalahan yang dihadapi dan harus dipecahkan oleh kelompok tani Dosroha dan kelompok tani Wanita Berkarya Desa Hutapuang Kecamatan Pollung- Kabupaten Humbang Hasundutan dilihat dari berbagai sudut pandang yang relevan.

1. Kolompok tani Dosroha dan Kelompok tani Wanita Berkarya pernah memproduksi ubi jalar menjadi keripik ubi secara konvensionl atau manual artinya menggunakan pisau biasa, sehingga hasilnya tidak maksimal, ukuran urisan ubi tidak sama (tidak sempurna). Setelah penggorengan tidak ada alat untuk meniriskan minyaknya, sehingga kripik yang diproduksi tidak tahan lama, melempem, dan tidak garing.

2. Mitra tidak memahami cara perhitungan Harga Pokok Produksi keripik ubi, sehingga sulit untuk menentukan harga jual. Mereka tidak dapat memisahkan biaya dan modal yang dikeluarkan dalam produksi keripik ubi. Sehingga dalam menentukan harga jual hanya mengacu pada kekuatan pasar yaitu permintaan dan penawaran.

3. Kelompok tani Dosroha dan kelompok tani Wanita Berkarya belum memiliki kemampuan dalam pemasaran hasil produk nya melalui media sosial. 


\section{Solusi yang Ditawarkan}

Berdasarkan analisis situasi dan permasalahan yang dihadapi oleh mitra, pelaksanaan kegiatan pengabdian (IbM) akan memberikan suatu solusi untuk mengatasi kesulitan mitra dalam pengolahan keripik ubi, kesulitan menghitung harga pokok produksi dan kesulitan pemasaran produk. Solusi yang ditawarkan kepada mitra adalah dengan transfer ipteks berupa pelatihan-pelatihan yang berkaitan dengan penggunaan Teknologi Tepat Guna (TTG) dalam pengolahan keripik ubi jalar, pelatihan perhitungan harga pokok produksi dan pelatihan menggunakan IT untuk pemasaran produk, serta dilakukan pendampingan kepada pihak mitra. Berikut solusi yang ditawarkan atas permasalahan mitra:

1. Melakukan pelatihan penggunaan Teknologi Tepat Guna untuk membuat kripik yang renyah dan garing, tahan lebih lama, cita rasa kripik bervariasi.

2. Secara bersama-sama mengidentifikasi jenis aktivitas, sumber daya yang akan digunakan dalam proses pembuatan keripik ubi, pemicu biaya yang mengakibatkan perubahan biaya aktivitas untuk selanjutnya menghitung biaya produksi berdasarkan aktivitas. Sebagai dasar penentuan harga pokok produksi dan harga jual.

3. Meningkatkan pemahaman dan keterampilan mitra dalam memasarkan produk secara on line

\section{TARGET DAN LUARAN}

Dari hasil pembahasan di atas, maka target dan luaran dari kegiatan Ipteks Bagi Masyarakat ini adalah sebagai berikut :

\section{Target}

Target yang ingin dicapai melalui kegiatan IbM ini adalah sebagai berikut:

1. Penyediaan peralatan yang dibutuhkan, seperti alat pengiris ubi dan spinner peniris minyak setelah peralatan tersebut diserahkan maka Kelompok tani Dosroha dan kelompok tani Wanita Berkarya desa Hutapaung dilatih untuk menggunakan alat tersebut sehingga mitra dapat memanfaatkan secara efektif untuk menghasilkan produk yang berkualias secara optimal. Mitra diharapkan mempunyai pemahaman tentang penggunaan sehingga hasil pertanian dapat bernilai tambah.

2. Pelatihan dan praktik menghasilkan produk berupa keripik ubi dengan menggunakan TTG sehingga dapat meningkatkan hasil produksi, yang di bimbing oleh pelaksana IbM. Kelompok tani Dosroha dan kelompok tani Wanita Berkarya diminta secara langsung mempraktekkan proses pengirisan dan pengeringan yang diperagakan oleh pelaksana IbM. Setelah pelatihan ini mitra diharapkan mempunyai jiwa enterpreunership yang makin meningkat.

3. Penentuan harga jual dilakukan dengan cara memperhitungkan harga bahan baku, upah pekerja, biaya-biaya lain yang berhubungan dengan proses produksi, dan pemasaran. Semua harga yang telah teridentifikasi dapat dihitung hingga bisa didapat harga satuan minimal (modal yang digunakan). 
Selanjutnya ditentukan harga jual, setelah menetapkan keuntungan yang ingin diperoleh. Hal yang perlu diingat dalam penetapan harga jual adalah jika harga ditentukan terlalu tinggi maka konsumen akan mempertimbangkan kembali untuk membeli produk kita dan lebih jauh lagi mereka akan lari ke produk lain yang sejenis.

4. Kelompok tani Dosroha dan kelompok tani Wanita Berkarya desa Hutapaung memiliki ketrampilan memasarkan produk keripik ubi melalui online

\section{Luaran}

Luaran yang diharapkan melalui kegiatan pengabdian IbM ini adalah sebagai berikut :

a. Laporan kegiatan.

b. Artikel

c. Blog promosi produk kelompok tani Dosroha dan kelompok tani Wanita Berkarya

\section{METODE PELAKSANAAN}

Dari hasil pengamatan permasalahan yang ditemukan pada kelompok tani Wanita Berkarya dan kelompok tani Dosroha, dan sesuai target luaran yang telah ditetapkan, maka kami menawarkan solusi yang dilaksanakan sebagai berikut:

1. Pemberitahuan lokasi tempat petemuan dan waktu pelaksanaan, serta penyediaan sarana dan prasarana untuk praktik. Peralatan praktik dan bahan praktik disediakn terlebih dahulu agar pelaksanan pelatihan berjalan lancar dan efisien, seperti ubi jalar, mesin pemotong ubi pengering keripik ubi, dan peralatan lainnya yang menunjang program ini.
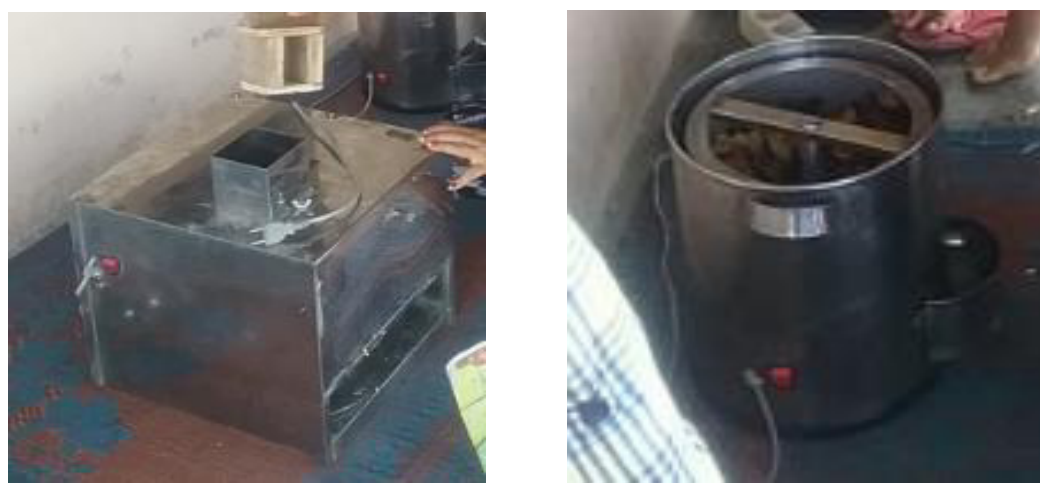

Gambar 2. Peralatan pengiris ubi dan alat peniris minyak

2. Memberikan penyuluhan kepada mitra, tentang nilai tambah yang didapatkan apabila ubi jalar dioalah lebih lanjut, kemudian dijual ke pasaran. Selain itu 
juga diberikan penyuluhan pemanfaatan ubi jalar apabila tidak laku di pasaran.

3. Memberikan pelatihan dan pendampingan pengolahan ubi jalar menjadi keripik ubi yang gurih, renyak dan tahan lama sesuai dengan kemampuan keterampilan yang dimiliki dan pada saat pembuatan proses kripik ubi dipantau agar sesuai dengan produk yang berkualitas. Pada tahap ini dilakukan demo langsung dengan bahan dan alat yang sudah disediakan.

Proses pembuatan keripik

Ubi jalar dikupas dan dicuci bersih kemudian diiris dengan mesin pengiris sehingga dihasilkan irisan tipis dan seragam. Setelah itu disiapkan campuran air dengan kapur sirih dan bumbu halus. Irisan ubi jalar selanjutnya direndam dalam campuran bumbu air dan kapur sirih selama \pm 30 menit, setelah itu diangkat dan ditiriskan. Ubi jalar selanjutnya digoreng dengan menggunakan api kecil sampai setengah matang kemudian dilanjutkan dengan menggoreng ubi jalar dengan panas yang maksimal sampai kering. Keripik yang sudah matang selanjutnya ditiriskan minyaknya dengan menggunakan mesin peniris sampai tidak ada minyak yang menempel pada keripik. Setelah ditiriskan maka keripik ubi jalar dapat diberi bumbu sesuai dengan varian rasa. Keripik yang sudah diberi bumbu siap untuk dikemas dan dipasarkan.
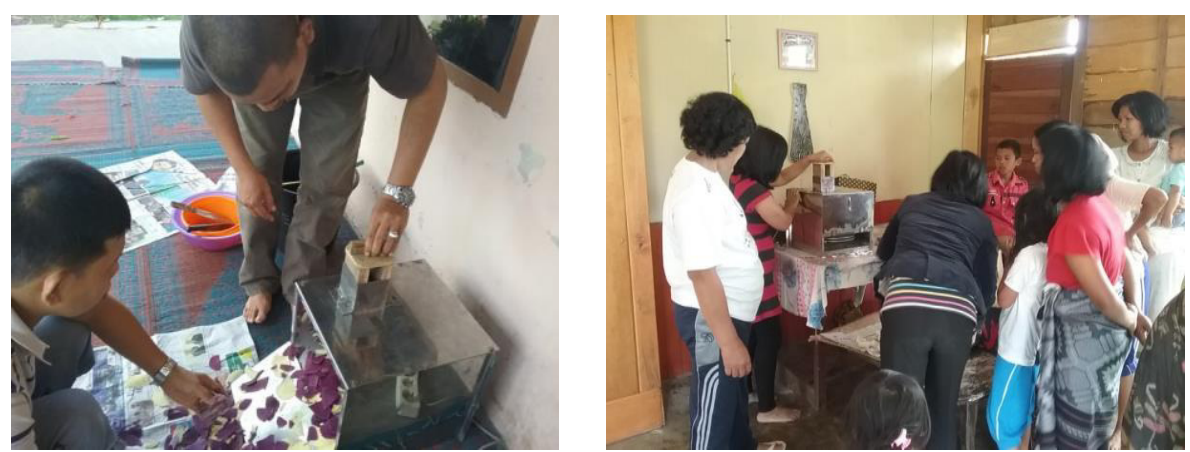

Gambar 3. Peserta yang mengikuti pelatihan penggunaan peralatan Teknologi Tepat Guna 


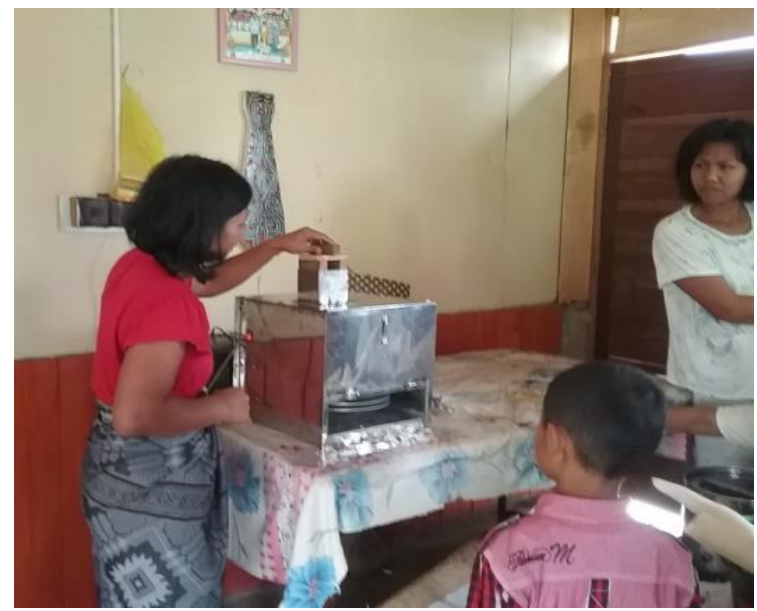

Gambar 4. Peserta mempraktekkan penggunaan peralatan Teknologi Tepat Guna

4. Memberikan pelatihan mengenai penentuan harga pokok produksi per $\mathrm{kg}$ kripik ubi yang layak dengan pemisahan antar biaya, modal dan harga pasar yang optimal. Dalam tahap ini akan di berikan cara perhitungan yang tepat dalam menentukan harga jual.
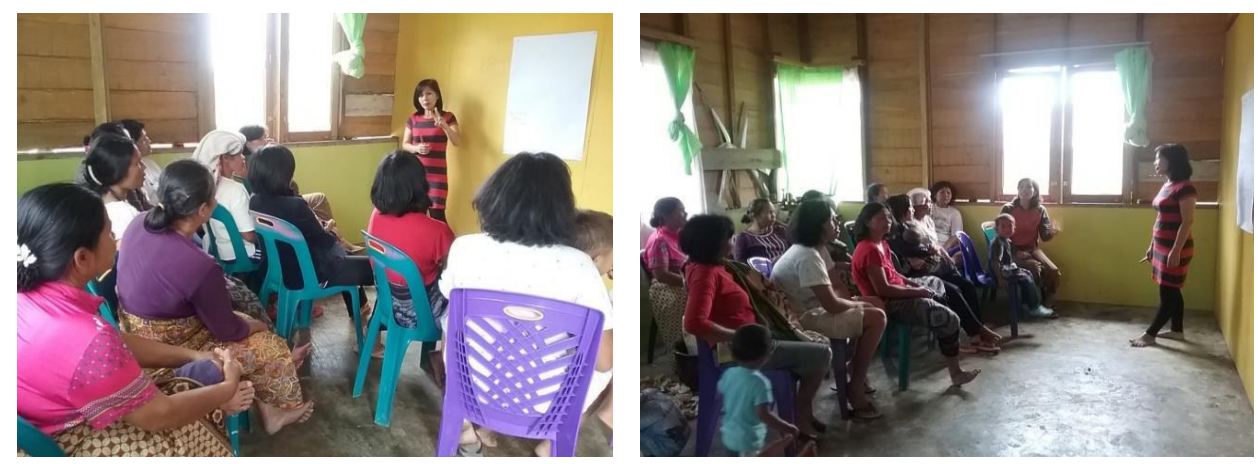

Gambar 5 Antusias kelompok dalam mengikuti pelatihan penentuan harga pokok produksi dan harga jual serta pembuatan pembukuan sederhana

5. Memberikan pelatihan pemasaran secara online melalui blog.

Memberikan pelatihan penggunaan jejaring sosial dan pemanfaatan blog untuk memasarkan produk yang dihasilkan.

\section{Keterlibtan mitra dalam pelaksanaan program IbM adalah:}

- Kehadiran mitra pada saat jadwal pelaksanaan penyuluhan atau pelatihan tiba.

- Penyediaan tempat untuk pelaksanaan penyuluhan dan pelatihan kepada mitra yaitu di rumah bendahara kelompok. 
- Pemberian fasilitas yang menunjang pemakaian peralatan misin pengiris ubi dan peniris minyak, yaitu listrik dan air.

- Menetapkan harga pokok penjualan dan harga jual berdasarkan target penjualan yang ditentukan.

- Melaksanakan tes rasa produk.

\section{KELAYAKAN PERGURUAN TINGGI}

\section{Kinerja Perguruan Tinggi dalam PPM}

Universitas Katolik Santo Thomas Suamtera Utara melakukan kegiatan PPM melalui Lembaga Penelitian dan Pengabdian pada Masyarakat. Setiap tahun terdapat anggaran yang bagi pelaksanaan kegiatan tersebut.

Kegiatan PPM adalah sebagai berikut

1. Pelatihan Simulasi Pembangunan Jariangan WAN Menggunakan Cisco Packet Tracer Pada SMK Swasta Yayasan Indonesia Membangun (YAPIM)

Taruna Belawan Medan

2. Pelatihan Pembuatan Game Dalam Bentuk Animasi 2D SMK Swasta Mulia Pratama Medan

3. Penyuluhan Fenomena Bisnis Dalam Paradigma Baru New Ekonomi Bagi Komunitas Informasi Masyarakat Desa Singa Kecamatan Tiga Panah Kabupaten Karo

4. Pelatihan Teknologi Mesin Pencari Informasi Bagi Masyarakat Desa Singa Kecamatan Tiga Panah Kabupaten Karo Desa Singa Kecamatan Tiga Panah Kabupaten Karo

5. Penyuluhan Peluang dan Ancaman Dalam Penggunaan Internet Bagi Masyarakat Desa Singa Kecamatan Tiga Panah Kabupaten Karo

6. Meningkatkan Kesejahteraan Keluarga Melalui Perkoperasian(FH)

7. Pembuktian Tingkat Pidana Penyalahgunaan Internet (FH)

8. Penyuluhan Tentang Kewajiban Hukum Orang Tua Terhadap Anak Dalam Rangka Pemberian Perlindungan Hukum (FH)

9. Pengaruh Teknologi Informasi Terhadap Perilaku Sosial Para Remaja

10. Pengaruh Keragaman Terhadap Kehidupan Beragama, Bermasyarakat dan Bernegara $(\mathrm{FH})$

11. Pencatatan Kelahiran Sebagai Upaya Perlindungan Hukum Terhadap Anak (FH)

12. Pendaftaran Tanah, Upaya Memperoleh Kepastian Hukum Kepemilikan Hak Atas Tanah (FH)

13. Peranan Koperasi Simpan Pinjam Dalam Pengembangan Perekonomian Desa Di Nagori Panombeian Kecamatan Panombeian Panei Kabupaten Simalungun (FE)

14. Penyuluhan Tentang Manajemen Usaha Kecil di Desa Cinta Damai Kecamatan Percut Sei Tuan Kabupaten Deli Serdang “

15. Berinvestasi di Asuransi Unit Linked Dengan Bijaksana di Kelurahan Tanjung Rejo Kecamatan Medan Sunggal Kota Madya Medan 
JENIS KEPAKARAN DI PERGURUAN TINGGI

\begin{tabular}{|c|c|c|c|c|c|}
\hline No. & Nama/NIDN & Instansi Asal & Unit Kerja & $\begin{array}{c}\text { Bidang } \\
\text { Kepakaran }\end{array}$ & $\begin{array}{l}\text { Uraian } \\
\text { Tugas }\end{array}$ \\
\hline 1 & $\begin{array}{l}\text { Romasi Lumban } \\
\text { Gaol ,SE,M.Si } \\
\text { NIDN : } \\
0109086301\end{array}$ & $\begin{array}{l}\text { UNIKA Santo } \\
\text { Thomas SU }\end{array}$ & $\begin{array}{l}\text { Fakultas } \\
\text { Ekonomi }\end{array}$ & $\begin{array}{l}\text { Akuntansi } \\
\text { Manajemen }\end{array}$ & 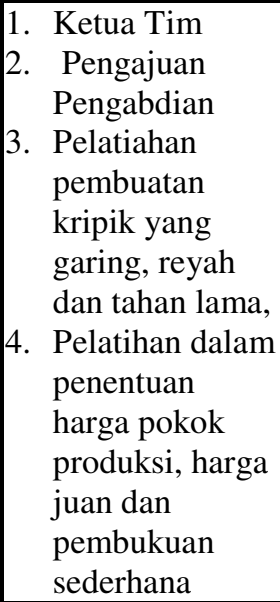 \\
\hline 2 & $\begin{array}{l}\text { Esli Silalahi, SE, } \\
\text { M.Si } \\
\text { NIDN: } \\
0128097301\end{array}$ & $\begin{array}{l}\text { UNIKA Santo } \\
\text { Thomas SU }\end{array}$ & $\begin{array}{l}\text { Fakultas } \\
\text { Ekonomi }\end{array}$ & $\begin{array}{l}\text { Manajemen } \\
\text { Keuangan }\end{array}$ & \begin{tabular}{|l} 
1. \\
Pelatihan \\
penyusunan \\
laporan \\
keuangan usaha \\
2. Pelatihan \\
Penyusunan \\
proposal untuk \\
memperoleh \\
tambahan dana \\
dari pemerintah \\
daerah atau \\
perbankan \\
3. Pelatihan \\
Dalam \\
Pemasaran on \\
line \\
4. Seminar dan \\
Publikasi
\end{tabular} \\
\hline
\end{tabular}

\section{HASIL DAN LUARAN YANG DICAPAI}

Pengabdian IbM pembuatan keripik ubi desa Hutapaung Kecamatan Pollung Kabupaten Humbang Hasundutan dibagi dalam beberapa tahap. Yang pertama penjajakan lokasi dan penggalian masalah yang terjadi pada kelompok mitra, hal ini dilakukan pada saat pembuatan proposal. Setelah diketahui permasalah mitra, yaitu masalah pemanfaatan ubi jalar agar bernilai tambah, karena tidak laku dijual. Disamping itu pengetahuan tentang pemanfaatan 
Teknologi Tepat Guna (TTG) dan peralatan yang tidak dimiliki mitra menyebabkan hasil bumi berupa ubi jalar tidak bisa diolah menjadi bernilai tambah

Kegiatan pengabdian IbM ini untuk memanfaatkan potensi yang ada di Desa Hutapaung, yaitu ubi jalar ungu. Dengan dimilikinya kemampuan dalam mengolah ubi jalar menjadi keripik ubi dengan menggunakan TTG, kemampuan menghitung harga pokok produksi, manajemen usaha serta pembukuan sederhana diharapkan bisa meningkatkan kesejahteraan masyarakat.

Kegiatan IbM sampai bulan Juli 2016 ini difokuskan pada kegiatan pelatihan dan pendampingan bagi para anggota kelompok tani Dosroha dan kelmpok tani Wanita Berkarya utamanya dalam penggunaan TTG untuk pengolahan ubi jalar menjadi keripik ubi. Pelaksanaan pengabdian pada masyarakat IbM ini melibatkan 2 (dua) kelompok tani yaitu, yaitu kolompok tani Dosroha dan kelompok tani Wanita Berkarya.

\section{HASIL KEGIATAN}

Sebagaimana penjelasan pada analisis situasi bahwa mitra tidak memiliki peralatan penunjang dalam proses produksi, selama ini pengolahan dilakukan secara manual dan konvensional, sehingga hasil olahan melempem dan tidak tahan lama. Penyuluh menyediakan sekaligus menyumbangkan peralatan tersebut yang merupakan peralatan TTG, berupa mesin pengiris ubi dan mesin spinner peniris minyak. Peralatan tersebut diserahkan kepada ketua kelompok tani Dosroha dan kelompok tani Wanita Berkarya yaitu Minta Lumban Gaol dan Lusi Manullang

1. Pendampingan pelatihan pengoperasian alat dalam pembuatan keripik ubi

Pada pelatihan pengoperasian alat, mitra dibimbing oleh pelaksana IbM menggunakan alat pengiris ubi dan alat spinner peniris minyak. Mitra satu persatu diminta untuk mencoba mengoperasikan dari proses awal sampai mematikan mesin. Pada kesempatan ini, mitra juga diberitahu ukuran bahan yang akan digoreng harus sesuai sehingga memberikan hasil akhir yang baik. Mitra juga diberikan pemahaman tentang keselamatan dalam pengoperasian alat.

Berkaitan dengan keberadaan mesin potong, yang selama ini mereka belum mengetahui, telah memberikan perubahan pandangan terhadap hasil pertanian lainnya yang terkadang terbuang pada saat musim tiba, karena harga murah akibat volume buah banyak. Dengan mengetahui TTG mesin pengiris ubi, mitra baru menyadari akan berharganya buah tersebut bila diolah menjadi keripik, dimana harganya cukup mahal. Dalam pelatihan yang diadakan, Mitra telah berhasil menjalankan mesin tersebut dan mampu mengolah ubi jalar menjadi keripik ubi yang kondisinya baik.

Selain mesin pengiris ubi yang telah dipahami mitra manfaatnya yang sangat besar, mitra juga memahami manfaat pentingnya alat spinner peniris minyak, 
dimana selama ini keripik yang mereka oleh tidak tahan lama dan sangat banyak mengandung minyak tapi dengan adanya alat mesin peniris minyak tersebut, keripik yang mereka olah menjadi lebih garing dan tahan lama dengan kualitas yang tidak kalah dengan produk keripik vakum yang selama ini ada dipasaran.

Diharapkan dengan kemampuan ini, mitra bisa membantu petani untuk menerima membeli) hasil panennya, dan mengolahnya menjadi keripik yang memiliki nilai jual lebih tinggi. Kegiatan ini diharapkan juga bisa membantu menyerap hasil panen petani dengan harga yang baik.

2. Pendampingan pelatihan perhitungan harga pokok produksi dan harga jual keripik ubi jalar, serta pembekuan sederhana.

Dalam pelatihan ini diharapkan mitra memiliki kemampuan dalam menentukan harga pokok produk dan harga jual keripik ubi. Pada dasarnya pelatihan dan pendampingan pembuatan pembukuan yang diberikan pada mitra adalah pembukuan sederhana yang merupakan sharing tentang bagaimana cara penentuan harga pokok produksi, penentuan harga jual dan membuat pembukuan yang baik bagi setiap usaha.

Pelatihan membuat pembukuan sederhana ditujukan untuk menentukan besarnya bahan baku, upah, dan biaya-biaya lain yang berhubungan dengan produk keripik ubi. Dari pelatihan pembuatan pembukan ini akan dapat ditentukan harga pokok produk dan harga jual keripik ubi, sehingga akan dapat ditentukan berapa laba/keuntungan dalam melaksanakan usaha pembuatan keripik ubi tersebut.

Setelah diberikan pelatihan perhitungan harga pokok produksi dan pelatihan pembukuan, maka hasilnya adalah, mitra memiliki kemampuan dan keterampilan yang memadai dalam menentukan harga pokok produk keripik ubi. Mempunyai kemampuan dalam menentukan harga jual keripik ubi. Mitra juga memahami cara pembuatan pembukuan yang sederhana yang digunakan untuk menghitung aliran masuk dan keluarnya dana.

Luaran yang dihasilkan dalam pelatihan ini adalah berupa laporan perhitungan harga pokok produk, laporan penentuan harga jual, dan pembukuan sederhana yang didalamnya memuat tentang uang masuk, uang keluar dan saldo. Berdasarkan pantauan kami pada pelatihan dan pendampingan pembuatan perhitungan harga pokok produk, penentuan harga jual dan pembuatan pembukuan sederhana, mampu dipahami mitra dengan baik.

Format perhitungan harga pokok produksi dan harga jual keripik ubi hasil olahan kelompok tani Dosroha dan kelompok tani Wanita Berkarya sebagai berikut: 


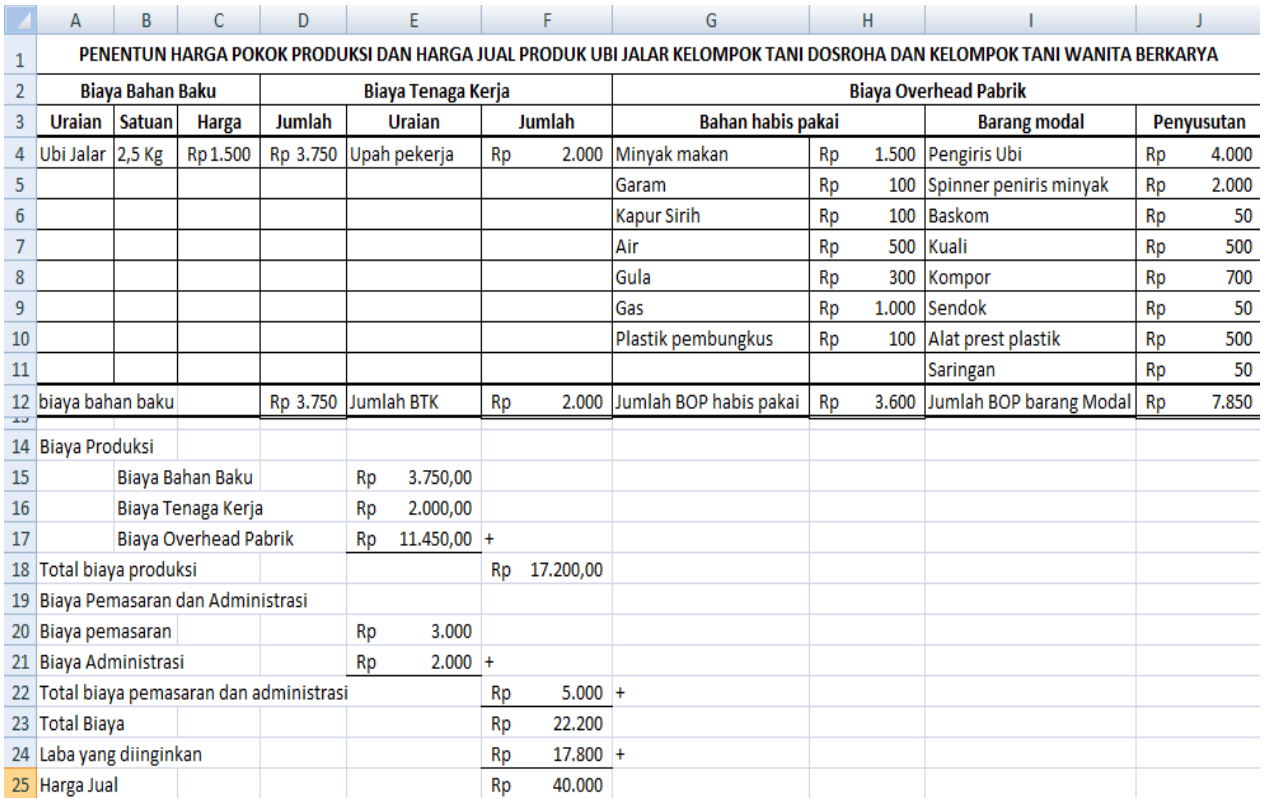

Gambar 6: Penentuan Harga Pokok Produksi dan Penentuan Harga Jual

Untuk pembukuan sederhana untuk usaha kecil dapat dibagi tiga kelompok yaitu

a. Buku kas pengeluaran atau belanja

Buku kas pengeluaran atau belanja adalah buku kas yang berhubungan dengan semua pengeluaran atau belanja dalam usaha. Seperti pengeluaran untuk belanja bahan baku, operasional maupun gaji karyawan. Buku kas pengeluran

\begin{tabular}{|c|c|c|c|c|c|c|c|}
\hline & A & $B$ & $c$ & & & & $E$ \\
\hline 1 & \multicolumn{7}{|c|}{ PEMBUKUAN SEDERHANA UNTUK USAHA KERIPIP UBI KELOMPOK TANI DOSROHA DAN KELOMPOK TANI WANITA BER } \\
\hline 2 & \multicolumn{7}{|c|}{ 1. BUKU KAS PEMBELIAN/PENGELUARAN } \\
\hline 3 & Tanggal & Kategori & Deskripsi & & inal & & aldo \\
\hline 4 & 20-Jun-16 & Beli Bahan & Pembelian Ubi Jalar 20 Kg @ Rp 1.500 & $\mathrm{Rp}$ & 30.000 & $\mathrm{Rp}$ & $(15.000)$ \\
\hline 5 & 20-Jun-16 & Beli Minyak Goreng dan Gas & $\begin{array}{l}\text { Pembelian minyak goreng } 2 \mathrm{Kg} @ \mathrm{Rp} 27.000 \text {, } \\
\text { pembelian gas } 2 \text { tabung @ Rp } 20.000\end{array}$ & $\mathrm{Rp}$ & 94.000 & $\mathrm{Rp}$ & $(109.000)$ \\
\hline 6 & 20-Jun-16 & Beli bahan pembantu & Pembelian kapur sirih & Rp & 2.000 & $\mathrm{Rp}$ & $(111.000)$ \\
\hline 7 & 20-Jun-16 & Beli bahan pembungkus & Pembelian plastik pembungkus & $\mathrm{Rp}$ & 5.000 & $\mathrm{Rp}$ & $(116.000)$ \\
\hline 8 & 22-Jun-16 & Bayar gaji & Gaji karywam & $\mathrm{Rp}$ & 50.000 & $\mathrm{Rp}$ & $(166.000)$ \\
\hline 9 & 23-Jun-16 & Beli Pulsa & Bayar biaya kominikasi & $\mathrm{Rp}$ & 10.000 & $\mathrm{Rp}$ & $(176.000)$ \\
\hline 10 & 23-Jun-16 & Biaya lain-lain & bayar air & $\mathrm{Rp}$ & 5.000 & $\operatorname{Rp}$ & $(181.000)$ \\
\hline
\end{tabular}

Gambar 7. Buku kas pengeluran

b. Buku kas penjualan/pemasukan

Buku kas penjualan/pemasukan adalah buku kas yang berhubungan dengan semua penjualan produk yang di produksi. Buku kas penjualan 
berfungsi untuk mencatat dan mengetahui semua uang pemasukan atau penjualan yang telah di dapat. Buku kas pemasukan.

\begin{tabular}{|c|c|c|c|c|c|c|c|}
\hline 4 & A & B & c & & D & & E \\
\hline 1 & \multicolumn{7}{|c|}{ PEMBUKUAN SEDERHANA UNTUK USAHA KERIPIP UBI KELOMPOK TANI DOSROHA DAN KELOMPOK TANI WANITA BERKARYA } \\
\hline 2 & & & & & & & \\
\hline 3 & \multicolumn{7}{|c|}{ 2. BUKU KAS PENJUALAN/PEMASUKAN } \\
\hline 4 & Tanggal & Kategori & Deskripsi & & minal & & aldo \\
\hline 5 & 30-Jun-16 & Penjualah eceran & Penjualan Eceran 2 bungkus @ Rp 40.000 & $\mathrm{Rp}$ & 80.000 & $\mathrm{Rp}$ & 80.000 \\
\hline 6 & 02-Jul-16 & Penjualan ke warung-warung & Penjualan warung 4 bungkus @ Rp 40.000 & $\mathrm{Rp}$ & 160.000 & $\mathrm{Rp}$ & 240.000 \\
\hline 7 & 03-Jul-16 & Penjualan eceran & Penjualan Eceran 1 bungkus @ Rp 40.000 & $\mathrm{Rp}$ & 40.000 & Rp & 280.000 \\
\hline 8 & 15-Jul-16 & Penjualan online & Penjualan online 1 bungkus & $\mathrm{Rp}$ & 40.000 & Rp & 320.000 \\
\hline
\end{tabular}

Gambar 8. Buku kas pemasukan

c. Buku kas utama

Buku kas utama adalah Penggabungan antara buku kas penjualan dengan buku kas pengeluaran. Sehingga hasil yang di dapat antara keuntungan dengan kerugian dapat di lihat secara jelas di dalamnya. Buku kas umum

\begin{tabular}{|c|c|c|c|c|c|c|c|}
\hline 4 & A & B & c & & D & & E \\
\hline 1 & \multicolumn{7}{|c|}{ PEMBUKUAN SEDERHANA UNTUK USAHA KERIPIP UBI KELOMPOK TANI DOSROHA DAN KELOMPOK TANI WANITA BERKARYA } \\
\hline 2 & & & & & & & \\
\hline 3 & \multicolumn{7}{|c|}{ 3. BUKU KAS UMUM } \\
\hline 4 & Tanggal & \begin{tabular}{|l|} 
Kategori \\
\end{tabular} & Deskripsi & & minal & & Ido \\
\hline 5 & 20-Jul-16 & Transfer dari pemasukan & Hasil penjualan & $\mathrm{Rp}$ & 320.000 & Rp & 320.000 \\
\hline 6 & 20-Jul-16 & transfer dari pengeluaran & Biaya membeli bahan dan lainnya & Rp & 181.000 & $\operatorname{Rp}$ & 139.000 \\
\hline
\end{tabular}

\section{Gambar 9. Buku kas umum}

3. Pelatihan pemasaran memalui media sosial

Dalam pelaksanaan pelatihan pemasaran melalui media sosial ini diharapkan Mitra memiliki ilmu dan kemampuan untuk memasarkan produk nya melalui fasilitas jejaring sosial. Mitra diharapkan dapat memahami bagimana cara memperlus pasar melalui media sosial. Setelah tim pelaksana IbM melakukan pelatihan, hasilnya sangat jelas nampak dimana mitra telah mempunyai kemampuan membuat blog untuk memasarkan produknya. Luaran yang dihasilkan pada pelatihan ini adalah mitra mampu membuat blog untuk memasarkan produknya.

\section{KESIMPULAN DAN SARAN \\ Kesimpulan}

Pengabdian IbM pengolahan keripik ubi telah dapat dijalankan dengan baik dan tanpa halangan yang berarti. Dengan kerjasama tim pelaksana IbM yang baik dan peran serta aktif dari mitra dalam kegiatan pelaksanaan IbM ini maka semuanya telah berjalan sesuai yang diharapkan. Harapan pelaksana IbM dapat 
memberikan manfaat bagi mitra yaitu kelompok tani Dosroha dan Kelompok tani Wanita Berkarya dalam keberlanjutan usaha dan pengolahan keripik ubi.

Kegiatan IbM telah dilakukan berupa pelatihan pemanfaatan peralatan TTG, pelatihan pengolahan keripik ubi, pelatihan penentuan harga pokok produk dan harga jual keripik ubi jalar, serta pelatihan pemasaran melalui online. Pelatihan diawali dengan pengenalan beberapa peralatan, kemudian dilanjutkan dengan pelatihan pembuatan keripik ubi, pelatihan penentuan harga pokok produk dan harga jual keripik ubi. Selanjutnya pelatihan pemasaran dengan media sosial secara online. Adanya kesadaran mitra bahwa dengan teknologi, banyak buah dari hasil pertanian/kebun mereka yang terbuang percuma, sebenarnya bisa dimanfaatkan dan menjadi bagian dari usaha mereka. Dengan adanya mesin pengiris ubi dan peniris minyak ini mereka sadar bahwa banyak potensi hasil kebun mereka (buah) yang selama ini terbuang ternyata dapat dijadikan penghasilan yang cukup banyak, karena keripik ini harga dipasar cukup mahal.

\section{Saran}

1. Agar pemasaran produk menjadi lebih luas maka perlu mendaftarkan produk yang dihasilkan kepada dinas kesehatan setempat sehingga memperoleh Sertifikat Produksi Pangan Industri Rumah Tangga / P-IRT.

2. Perlu melakukan diversifikasi produk, sehingga mitra dapat menghasilkan beberapa jenis produk yang terbuat dari satu jenis bahan baku.

3. Perlu pendampingan dalam mendesain kemasan agar mendapat merek dagang.

\section{DAFTAR PUSTAKA}

Carter K. William. 2009. Akuntansi Biaya, Buku 1, Edisi 14 Penertbit Salemba Empat Jakarta.

Eugene F. Brigham \& Joel Houston. 2008 Manajemen Keuangan, Buku Satu Penerbit Salemba Empat Jakarta.

http://id.wikipedia.org/wiki/Usaha Kecil dan Menengahberandaukm.blogspot.co $\underline{m}$

James M. Reeve Carl S. Warren, 2009. Pengantar Akuntansi Adaptasi Indonesia, Buku satu Penerbit Salemba Empat Jakarta.

Peraturan Presiden RI Nomor 13 Tahun 2009 tentang Koordinasi Penanggulangan Kemiskinan.

Martani Dwi, at all. 2012. AKUNTANSI KEUANGAN MENENGAH Berbasis PSAK Buku 1,Penerbit Salemba Empat Jakarta 